Konrad Sikora, Dialogiczne aspekty dzieta sztuki, [w:] Cztowiek w relacji do...

Rozważania o cztowieku jako istocie relacyjnej, red. Grzegorz Wąchol,

Kraków 2020, s. 55-73.

DOI: http://dx.doi.org./10.15633/9788374388740.04

MGR KONRAD SIKORA

\title{
Dialogiczne aspekty dzieła sztuki
}

\section{Zakreślenie obszaru badań}

Koncepcja dzieła sztuki jest jednym z najbardziej zawiłych i rozwiniętych zagadnień z zakresu estetyki. Próba wyczerpania tematu niesie ze sobą spore trudności. Jednakże taki stan rzeczy stwarza również nowe możliwości spojrzenia na to zagadnienie. U progu rozważań należy określić, jak rozumiemy pojęcie dialogu i o jakiej koncepcji dzieła sztuki mamy zamiar mówić.

Przez dialog rozumiemy proces mający na celu inicjowanie i umacnianie więzi, tworzenie wspólnoty, współpracę zmierzającą do integralnego rozwoju jednostek, a w dalszej perspektywie poszczególnych grup od tych najmniejszych i najbardziej podstawowych aż po grupy etniczne i narodowe. Dialog cechuje się uznaniem równości, godności i wolności wszystkich osób w nim uczestniczących oraz zakłada prawo do wyrażania swoich poglądów. Podkreśla się, że w dialog angażują się wszystkie wymiary osobowości człowieka: intelektualny, wolitywny oraz emocjonalny, przez co dochodzi do wzajemnego udzielania się osób i wypracowania 
pewnej międzypodmiotowej rzeczywistości ${ }^{1}$. Istotnym jednakże dookreśleniem tak pojętego dialogu jest wprowadzenie do nurtu filozofii dialogu pojęcia dramatu, jakiego dokonuje Józef Tischner. Pisze on, że człowiek jest istotą dramatyczną, a rozumie to następująco: „[...] być istotą dramatyczną znaczy: przeżywać dany czas, mając wokół siebie innych ludzi i ziemię jako scenę pod stopami. Człowiek nie byłby egzystencją dramatyczną, gdyby nie te trzy czynniki: otwarcie na innego człowieka, otwarcie na scenę dramatu i na przepływający czas"2. Tak ujęty człowiek staje się istotą otwartą na to, co go otacza. Dialogiczność zatem, tak jak chcemy ją tutaj rozumieć, jest umiejętnością otwierania się na to, co przychodzi spoza nas, i równocześnie wyprowadzania $z$ siebie koniecznej odpowiedzi na to, co do nas dotarło, ponieważ dialog zakłada równość stron dialogujących ze sobą.

Pytając o dzieło sztuki, mamy do czynienia $z$ wieloma różnymi punktami widzenia. Wydaje się, że na pytanie: „Co to jest dzieło sztuki?” w sposób najbardziej kompletny odpowiada definicja pochodząca od Jacques'a Maritaina, który uważa, że „dzieło sztuki stanowi wytwór człowieka, który jest zarazem homo faber i homo poeta" . Dzieło sztuki traktujemy zatem jako wytwór człowieka. Nie musi ono być artefaktem, gdyż tak pojęte, pomija szereg czynności będących dziełami sztuki ${ }^{4}$. Dzieło sztuki również nie musi być wytworem ukończonym. Pomijamy zatem kwestię jego

1 Por. M. Żardecka, Dialog, w: Leksykon filozofii klasycznej, red. J. Herbut, Lublin 1997, s. 114-116.

2 J. Tischner, Filozofia dramatu, Kraków 2012, s. 7.

3 J. Maritain, Creative Intuition in Art and Poetry, Cleveland-New York 1961; cyt. za: W. Stróżewski, Dzieto sztuki, w: W. Stróżewski, P. Taranczewski, Lubelskie wykłady o estetyce, Kraków 2016, s. 115.

$4 \mathrm{Na}$ przykład perfomance'y czy też spektakle teatralne, wykonania utworów muzycznych, jak choćby interpretacje mazurków Chopina w wykonaniu Marthy Argerich. 
skończoności, nie rozpatrujemy, czy jest niedokończone z przyczyn obiektywnych, czy zarzucone z przyczyn subiektywnych, chociaż te drugie mogą nieść ze sobą konkretny komunikat. Dzieło sztuki jest pojmowane przez pryzmat kilku aspektów: formy, treści, walorów estetycznych i wyjątkowości. To gwarantuje mu indywidualność i rozpoznawalność. Przytoczony wcześniej przykład wykonania mazurków przez Marthę Argerich (zob. przyp. 4) pokazuje, że ta interpretacja wybitnej pianistki nosi w sobie rys indywidualny i przez uważnych słuchaczy będzie ona odróżniana od szkolnego wykonania początkującego pianisty. Zawężenie ujmowania dzieła sztuki w kategoriach formy, treści, walorów estetycznych i wyjątkowości okazuje się niewystarczające i spłycone. Dlatego też odpowiednim do naszego badania sposobem wydaje się propozycja wysunięta przez Władysława Stróżewskiego, jakoby dzieło sztuki najlepiej było ujmować w trzech aspektach: ontologicznym, aksjologicznym i semiotycznym (w szczególności semantycznym) $\mathrm{W}$ aspekcie ontologicznym rozpatrujemy dzieło sztuki z punktu widzenia ontologii. W tym miejscu mówi się więc o trzech podstawowych grupach zagadnień:

a) problematyce genezy dzieła sztuki;

b) problematyce sposobu istnienia;

c) problematyce jego struktury.

Z powyższymi zagadnieniami wiążą się kolejne dwa: zagadnienie tożsamości dzieła oraz stosunku formy do treści.

Aspekt aksjologiczny rozpatruje dzieło sztuki jako fundament (nośnik) określonych wartości, które muszą w nim być obecne, aby dzieło mogło być dziełem sztuki.

W aspekcie semiotycznym dzieło sztuki rozważa się przez pryzmat jego funkcji semiotycznej, szczególnie zaś semantycznej, a zatem funkcji odniesienia dzieła jako znaku do pewnej rzeczywistości

5 Por. W. Stróżewski, Dzieto sztuki, dz. cyt., s. 113. 
poza nim samym. Możliwe funkcje dzieła sztuki w tym aspekcie to: funkcja znaczenia, prezentowania, reprezentowania (a zatem symbolizowania lub wyrażania) itp. W zakres tych rozważań wchodzi także kwestia, czy posiadanie funkcji semantycznej jest stałą cechą dzieła sztuki jako takiego, której nie można od niego odłączyć, oraz w jakim stopniu jest ona realizowana ${ }^{6}$. To podstawowe ujęcie pozwoli przebadać zagadnienie, które stanowi przedmiot niniejszego artykułu.

Podstawowe pytanie, jakie należy postawić, brzmi: czy dzieło sztuki zawiera w sobie elementy, które pozwalają na ukonstytuowanie się dialogu? I dalej: jeśli dialog zaistnieje, jaki jest to dialog?

Mając przed oczyma dzieło sztuki, możemy dostrzec przynajmniej trzy możliwe podmioty dialogu. Pierwsze dwa są oczywiste: jest to twórca i odbiorca. Trzeci podmiot to dzieło sztuki, niosące ze sobą konkretną treść. Hipotetycznie można więc powiedzieć o trzech możliwych dialogach: między twórcą a odbiorcą, między odbiorcą a dziełem oraz między twórcą a dziełem. Spróbujmy zatem przebadać wszystkie trzy warianty, uwzględniając cały czas obecność dzieła sztuki wewnątrz dialogu lub - w ostatnim przypadku - jego istnienie jako jednego z podmiotów dialogu.

\section{Dialog między twórcą a dziełem}

Odnosząc się do pierwszej możliwości dialogicznej, nie sposób nie wspomnieć o badaniach Stróżewskiego, który wnikliwie prześledził ów proces. Filozof nazywa taki dialog dialogiem twórczym. Dialog dokonuje się w atmosferze szczególnego napięcia, tzn. wytężenia wszystkich władz podmiotu, choć nie zawsze muszą one być aktywne; dopuszcza się także oddziaływanie pasywnie aktywne

6 Por. W. Stróżewski, Dzieto sztuki, dz. cyt., s. 113-114. 
(kontemplacyjne), wyrażające się we wpatrywaniu, wsłuchiwaniu się, a nawet wczuwaniu się w to, co powstaje. Ze strony twórcy wejście w dialog dokonuje się więc bardzo wyraźnie. Twórca wpatruje się w dzieło, poznaje je w każdym możliwym aspekcie, przez co sam proces twórczy nabiera tempa i coraz to nowej jakości. Jednakże pojawia się pytanie, w jaki sposób dzieło wchodzi w dialog z twórcą. Stróżewski zauważa, że dzieło wystarczy, że ukazuje się i odsłania ${ }^{7}$. Dzieło sztuki zatem jako samo z siebie odsłania się i prezentuje. Nie robi tego wolitywnie, gdyż nie jest bytem rozumnym. Jednakże trzeba zauważyć, że najważniejsze tutaj jest bycie widocznym, co zresztą jest jedną z najważniejszych właściwości dzieła sztuki ${ }^{8}$.

Bardzo ważne zastrzeżenie uczynił Stróżewski, mówiąc o dialogu dokonującym się w ramach procesu twórczego. Dzieło sztuki, powstając, dialoguje $z$ twórcą ciągle aż do momentu wyczerpania się bądź po prostu zaprzestania tegoż dialogu. Wówczas zdaniem filozofa dobiega końca proces twórczy i dzieło staje się transcendentne względem twórcy ${ }^{9}$.Jeżeli przyjąć za Tischnerem, że dialog jest źródłem sensu, bo obecność innego jest obecnością innego źródła sensu ${ }^{10}$, to dla zaistnienia twórczego dialogu potrzeba dopełnienia ukonstytuowanego w dziele sztuki. Stróżewski zwraca uwagę, że dopełnienie nie musi zaistnieć w dziele ukończonym, może dziać się wraz z dzianiem się dzieła: czy to z jego powstawaniem, np. dzieła sztuki literackiej lub malarskiej, czy też wraz z jego istnieniem, jak w przypadku wykonywania utworu muzycznego bądź

7 Por. W. Stróżewski, Dialektyka twórczości, Kraków 1983, s. 207.

8 Dzieło sztuki, jak zauważa Roman Ingarden, jest przedmiotem intencjonalnym, skierowanym ku czemuś, a zatem musi być w jakiś sposób widoczne, rozumiane, słyszane itd. Zob. na ten temat np. R. Ingarden, O dziele literackim, Warszawa 1960.

9 Por. W. Stróżewski, Dialektyka twórczości, dz. cyt., s. 207-208.

10 Por. J. Tischner, Epizody sensu, w: J. Tischner, Inny. Eseje o spotkaniu, Kraków 2017, s. 65. 
odgrywania spektaklu teatralnego ${ }^{11}$. Wynika stąd, że skończoność dzieła nie ma zasadniczego wpływu na dialog twórcy z nim.

Sam proces konstytuowania się dialogu między twórcą a dziełem wydaje się przejrzysty. Dzieło sztuki, które w miarę postępowania procesu twórczego odsłania się coraz bardziej, staje się coraz wyraźniej partnerem dialogu, zajmuje pozycję równą pozycji twórcy. Wydawałoby się, że im bardziej twór staje się czymś nowym, bardziej dojrzałym i skończonym, tym bardziej dialog się wyczerpuje. Stróżewski zauważa jednak, że dzieje się zupełnie odwrotnie: im dzieło bardziej skończone, tym bardziej zobiektywizowane i bardziej autonomiczne ${ }^{12}$. Należy przecież pamiętać, że uczestnicy dialogu powinni być sobie równi. Jeżeli dzieło zajmuje pozycję $\mathrm{w}$ pełni autonomiczną, wówczas może wejść w dialog z twórcą.

W związku z powyższym rodzi się pytanie o treść dialogu, jaka występuje między twórcą a dziełem. Każde dzieło sztuki posiada samo w sobie określony sens. Stanowi go określony temat dzieła, sposób prezentacji owego zamysłu, techniki wykonania, wartości, jakie przekazuje (od estetycznych po etyczne). Obok sensu dzieła pojawia się jeszcze wewnętrzna logia wytworu ${ }^{13}$ odsłaniająca je w całej jego krasie. To właśnie odsłanianie się dzieła stanowi jego dialogiczny akt, natomiast po stronie twórcy owym dialogicznym aktem będzie działanie. Twórca, wchodząc w dialog, ma szansę dokonać oceny dzieła, korygować jego wygląd lub dodawać kolejne elementy, stąd ów dialog nazywa się dialogiem twórczym. Treścią dialogu między twórcą a dziełem będą więc: sens i logika odsłaniającego się dzieła i zamysł artysty, który go realizuje w dziele. Toczący się dialog nie może wpływać pozytywnie jedynie na dzieło, które staje się coraz doskonalsze. Stróżewski uważa,

11 Por. W. Stróżewski, Dialektyka twórczości, dz. cyt., s. 212.

12 Por. W. Stróżewski, Dialektyka twórczości, dz. cyt., s. 212-213.

13 Zob. W. Stróżewski, Dialektyka twórczości, dz. cyt., s. 212-213. 
że w procesie twórczym (a zatem i w dialogu, który zachodzi w ramach tego procesu) chodzi o autentyczne wyważenie „za” i „przeciw” mającego się podporządkować jedynie wartości powstającego dzieła ${ }^{14}$. Chociaż w dialogu chodzi o wypracowanie kompromisu, dojście do prawdy czy ustąpienie wyższym wartościom, to jednak rodzi się pytanie, czy twórca $z$ tego dialogu wychodzi zawsze jako ten, który robi wszystko dla dzieła, czy może akt twórczy jest nakierowany wyłącznie na doskonałość dzieła i artyście nie przynosi nic poza satysfakcją dobrze wykonanej pracy twórczej.

Choć u Stróżewskiego trudno znaleźć explicite wypowiedź na temat tego, jak dialog między twórcą a dziełem wpływa na samego twórcę inaczej niż przez dostarczenie wspomnianej satysfakcji, to wydaje się nieodzowne podjąć rozważania prowadzące nie tylko do skwitowania, że owocem dla twórcy jest satysfakcja i poczucie twórczego spełnienia. Dzięki bardzo ważnemu zastrzeżeniu, jakie stawia Stróżewski, broniąc dialogiczności relacji twórca-dzieło ${ }^{15}$, można podjąć próbę odpowiedzi na pytanie: co twórca zyskuje na dialogu ze swoim dziełem?

W aspekcie ontologicznym dzieła sztuki to, co wydaje się szczególnie przemawiać do twórcy pozostającego w dialogu z własnym dziełem, to geneza tegoż dzieła. Stojące u początku procesu twórczego pomysł czy też swoiste oświecenie, natchnienie, poruszenie duchowe zazwyczaj niosą ze sobą konkretne powody, dla których dzieło zostało zrealizowane. Racje te wiążą się z konkretnymi wspomnieniami, choć przeżycia autora niekoniecznie muszą

14 Por. W. Stróżewski, Dialektyka twórczości, dz. cyt., s. 215.

15 Stróżewski zdaje sobie sprawę, że w przypadku relacji twórca-dzieło nie można mówić o dialogu w pełnym znaczeniu tego słowa; w relacji tej zachodzą jednak momenty charakterystyczne dla dialogu między ,ja” i „ty”. Są to: bycie pomiędzy, obecność i jedyność (zob. W. Stróżewski, Dialektyka twórczości, dz. cyt., s. 215). 
znaleźć swoje odbicie w dziele. Najbardziej rozpowszechnione opinie na temat dzieł sztuki odnoszą się, co prawda, w jakiejś mierze do osobistych doświadczeń autora, np. Pan Tadeusz Adama Mickiewicza jest wyrazem jego nostalgii za krajem lat dziecinnych, Sonety Williama Szekspira prezentują jego skomplikowaną sferę uczuciową. Niemniej jednak nie oznacza to wcale, że Olga Tokarczuk przeżywała w trakcie pisania powieści Prowadź swój ptug przez kości umartych te same uczucia i stany co jej bohaterka Janina Duszejko. Wydaje się, że wystarczy np. samo wspomnienie okresu pracy nad dziełem, być może przewertowanie dzienników z tamtego okresu, stanowiących nośnik cennych informacji, by dialog dostarczył twórcy wiedzy pozwalającej na wyprowadzenie określonych wniosków o sobie samym i o dziele. Inną sprawą będą przykłady dzieł o charakterze autobiograficznym. Jakkolwiek każdy z wyżej wymienionych utworów może zawierać w sobie jakieś elementy tożsame $\mathrm{z}$ życiem prywatnym twórcy, to jednak daleko im będzie do utworów, których zasadniczy zrąb ukształtowała jego biografia. Wystarczy wymienić tutaj chociażby jedną z głośniejszych powieści ostatnich lat, np. Historie przemocy francuskiego pisarza Éduarda Louisa ${ }^{16}$, czy klasyczne już opowiadania Tadeusza

16 Édouard Louis, właśc. Eddy Bellegueule (ur. 1992) - francuski pisarz. Jego pierwsza autobiograficzna powieść En finir avec Eddy Bellegueule (wydana w Polsce przez Wydawnictwo Pauza w 2019 roku jako Koniec z Eddym) odniosła niebywały sukces: autor w wieku 22 lat otrzymał pierwszą w życiu nominację do Nagrody Goncourtów, jednej z najbardziej prestiżowych nagród literackich na świecie, a debiutancka powieść sprzedała się we Francji w nakładzie ponad 300 tys. egzemplarzy i została opublikowana za granicą w dwudziestu pięciu językach. Od tego czasu Louis napisał dwie kolejne osnute na faktach powieści: opublikowaną w 2016 roku Histoire de la violence (wydaną w Polsce przez Wydawnictwo Pauza w 2018 roku jako Historia przemocy) i Qui a tué mon père, która ukazała się w maju 2018 roku [zob. http://wydawnictwopauza. pl/edouard-louis/ (13.10.2019)]. 
Borowskiego oparte na osobistych przeżyciach autora. Wymienione utwory są efektem traumatycznych przeżyć, więc można postawić hipotezę, że dialog z dziełem może stanowić formę autoterapii, próbę rozliczenia się z tamtymi wydarzeniami i poukładania w sobie bolesnej przeszłości. Jednakże istnieją dzieła autobiograficzne, które niekoniecznie traktują o traumatycznych wydarzeniach, nie muszą więc stanowić formy terapii, a sama przeszłość może być bardzo dobrze poukładana. To, co możliwe jest w przypadku dzieł autobiograficznych opierających się na trudnych, niekiedy tragicznych przeżyciach, nie będzie możliwe tam, gdzie ich po prostu brakuje.

Aspekt aksjologiczny dzieła sztuki jest bardzo rozbudowany i bynajmniej nie sprowadza się do samych tylko estetycznych wartości dzieła sztuki. W dziele mogą konstytuować się także inne wartości: prawdziwościowe, etyczne, artystyczne, sakralne, religijne itd. Warto dodać, że konkretyzacja tychże wartości może dokonywać się nie tylko w dziele, ale także poprzez dzieło i na jego podstawie ${ }^{17}$. Dzieło sztuki dane w ten sposób twórcy jest spotkaniem $z$ ukonstytuowanymi tam wartościami. Chociaż wartości te wypływają z osoby twórcy, który je tam umieścił, to jednak poprzez dzieło sztuki stają się one transcendentne względem twórcy, podobnie jak dzieło samo w sobie. Transcendentność wartości względem twórcy powoduje, że zaczynają one istnieć podobnie jak „ty” w spotkaniu $\mathrm{z}, \mathrm{ja}^{\prime \prime 18}$. Wartości te są zatem poddawane ocenie, są konfrontowane z aktualną aksjologią autora. Czas wydaje się tutaj bardzo ważny, system wartości może bowiem ulegać zmianie. Jeżeli twórca powraca do dzieła sprzed wielu lat, z okresu, w którym kierował się zupełnie innym systemem niż obecnie, wówczas konfrontacja

17 Por. W. Stróżewski, Dzieto sztuki, dz. cyt., s. 139.

18 Czynimy zastrzeżenie „podobnie”, bo jak wspomniano, dzieło sztuki nie stanowi „ty” w relacji do ,ja” twórcy. 
będzie wnikliwsza i być może bardziej krytyczna. Może dojść do usprawiedliwienia ${ }^{19}$ wartości dzieła (mamy na myśli wszystkie konstytuujące się wartości w danym dziele i poprzez dzieło), może dojść do odmowy tegoż usprawiedliwienia, czyli potępienia, wyrzucenia $\mathrm{z}$ przestrzeni obcowania ${ }^{20}$, lub do kompromisu, co stanowi owoc „zwyczajnego” dialogu ${ }^{21}$.

Autor z takiego dialogu może więc wyjść zbudowany lub rozbity. Jeżeli twórca usprawiedliwia istnienie dzieła, wówczas wychodzi z dialogu jako ten, dla którego spotkanie stało się wydarzeniem sensu. Twórca powie: „Oto moje dzieło”, dzieło powie: „Oto mój twórca”. Sensem będzie więc budowanie tożsamości, która może istnieć tylko dzięki usprawiedliwieniu: „Tak, ty masz prawo tutaj być, w mojej przestrzeni”. Potępienie może przyjść również z dwóch stron: od artysty i od dzieła. Potępia ten, kto jest wyżej (albo komu wydaje się, że jest wyżej). By kogoś (lub coś) potępić, trzeba mieć władzę potępiania. Artysta może zwrócić się do dzieła: „Nie jesteś mnie godne i żałuję, że cię wytworzyłem”. Ponieważ dzieło, mimo swej autonomii, jest nośnikiem wartości, z którymi identyfikował się w jakiś sposób artysta, potępienie dzieła jest w dalszej perspektywie potępieniem siebie. Głębsze analizy mogłyby wykazać istotne aspekty takiego zjawiska, jednakże z uwagi

19 Usprawiedliwienie rozumiemy tutaj dialogicznie: jako dopuszczenie istnienia „ty” względem „ja”, uznanie jego równości i godności; usprawiedliwienie konstytuuje sens dialogu, bo pozwala drugiemu być (zob. J. Tischner, Filozofia dramatu, dz. cyt., s. 306nn).

20 Przestrzeń obcowania $z$ drugim rozumiana jest tutaj przede wszystkim jako przestrzeń aksjologiczna, która zdaniem Tischnera wyznacza granicę dopuszczającą „ty” do istnienia obok ,ja” (powiedzielibyśmy: „z ja”) lub wyrzuca „ty” poza przestrzeń istnienia „z ja” (zob. J. Tischner, Filozofia dramatu, dz. cyt., s. 267nn).

21 Mówiąc „zwyczajny dialog”, rozumiemy tutaj wymianę zdań i poglądów, poddanie weryfikacji, przedyskutowanie jakiejś kwestii zmierzające do kompromisu. 
na szczupłość artykułu musimy skonstatować, że stosunek twórcy do dzieła nie pozostaje bez wpływu na stosunek do samego siebie. Potępienie pochodzące ze strony dzieła oznajmia, że artysta nie jest godzien swojego dzieła. Tischner takie potępienie rozważa w kategoriach estetycznych, mówiąc, że dzieło sztuki jako piękne potępia tego, kto jest szpetny ${ }^{22}$. Wydaje się jednak, że przyjęcie takiego stanowiska może okazać się niewystarczające. Nie uwzględnia bowiem innych wartości, które konstytuują się w dziele lub przy jego pomocy. Dzieło może nie tylko mówić, że jest piękniejsze niż sam artysta, może także oznajmiać, że lepiej opowiada świat niż on sam, że jest bardziej moralne niż on sam itd. Na takie zarzuty człowiek próbuje odpowiedzieć, gdyż szuka on usprawiedliwienia i walczy o nie, ale walka odbywa się na płaszczyźnie dialogicznej, co oznacza, że walczyć o usprawiedliwienie, to przekonać „ty” do tego, że „ja” ma prawo istnieć, ale istnieć w bliskości. W tej perspektywie dialogiczność dzieła sztuki ma wielkie znaczenie w budowaniu tożsamości twórcy. Jeżeli dzieło usprawiedliwia lub potępia ${ }^{23}$, to oznacza, że twórca w spotkaniu z nim (nawet przy ponownym spotkaniu) wszedł $\mathrm{w}$ dialog $\mathrm{z}$ wartościami niesionymi przez nie i dokonał (lub nie) reinterpretacji owych wartości, a w tego wyniku - skonfrontował się w jakimś stopniu ze swoim „ja”, co z pewnością nie będzie obojętne względem poznawania swojej tożsamości.

\section{Dialog między twórcą a odbiorcą}

Kolejną odsłoną możliwego dialogu jest relacja konstytuująca się między dwoma właściwymi, osobowymi podmiotami: twórcą

22 Zob. J. Tischner, Filozofia dramatu, dz. cyt., s. 300-301.

23 Nie można mówić tutaj oczywiście o jakimś wolitywnym akcie. 
i odbiorcą. Wypada znów sięgnąć po analizy Stróżewskiego, który spojrzał na ów dialog, ale tylko w procesie twórczym.

Stróżewski zadaje pytanie o rolę odbiorcy w procesie twórczym. Słusznie zauważa, że najbardziej wymownym przykładem odbiorcy realnego jest odbiorca, który bierze udział w spektaklach i happeningach i staje się ich czynnym elementem lub swoistym tworzywem. Reakcje widzów na widziane przedstawienia nie muszą być jednak radykalne ani też programowane przez twórców, jak podkreśla filozof. Oddziaływanie daje się wyczuć w atmosferze np. koncertu, podczas którego jego zdaniem zachodzi kontakt między artystą a słuchaczem. Prawdą jest, że odbiorca tworzący odpowiednią atmosferę skupienia, a tym samym wejścia w przestrzeń dzieła, buduje pełną napięcia obecność, wyczuwaną przez wykonawcę - artystę ${ }^{24}$. Już tutaj zachodzi zdaniem Stróżewskiego dialog, choć niekoniecznie muszą padać słowa (nawet $z$ jednej tylko strony). Wystarczą do tego dwa akty: akt twórczy po stronie artysty i akt skierowania uwagi na dziejące się dzieło - po stronie odbiorcy. Ta sytuacja jest w stanie dodać więcej walorów wartościujących powstającemu dziełu niż w przypadku, gdy jest ono grane w sytuacji pozbawionej elementów dialogicznych ${ }^{25}$. Często można spotkać się z wypowiedziami twórców, zwłaszcza aktorów, artystów estradowych, że dużo lepiej się gra, gdy widzi się reakcje publiczności. Dzieło sztuki nie wyznacza jedynie pewnej przestrzeni, w której ramach dokonuje się dialog, staje się także owocem tego dialogu. Trzeba jednak zaznaczyć, iż dialog ten nie jest radykalny, można nawet stwierdzić, iż jest w pewnym sensie intuicyjny, bo nie pada żadne zdanie, żaden czytelny komunikat. Jedynym komunikatem jest współtworzony nastrój wśród ludzi skupionych wokół dzieła: twórców i odbiorców. Bardziej radykalną

24 Por. W. Stróżewski, Dialektyka twórczości, dz. cyt., s. 216-217.

25 Por. W. Stróżewski, Dialektyka twórczości, dz. cyt., s. 216-217. 
sytuacją dialogiczną jest ingerencja odbiorcy w proces twórczy. Również tutaj pojawia się jakiś owoc owego dialogu zmieniający jakość dzieła (nie zawsze na jego korzyść). Bywa, że taka ingerencja może być gwałtowna, wywołana jakimś konkretnym aktem artysty, np. kontrowersyjną sceną domagającą się wyraźnej reakcji od widzów, jak ma to miejsce szczególnie w spektaklach interaktywnych, lub jest wyrażana spontanicznie przez widzów, np. poprzez oklaski nagradzające brawurową grę. Dzieło sztuki okazuje się tutaj już nie tylko przestrzenią obcowania i owocem dialogu czy też komunikatem, na który można odpowiedzieć intuicyjnie, przez wytworzenie atmosfery. Staje się bowiem komunikatem wypowiedzianym wprost do odbiorcy $z$ oczekiwaniem na jego odpowiedź (inaczej jednak niż w tzw. spektaklach interaktywnych, $\mathrm{w}$ których reakcja publiczności jest expressis verbis ujęta $\mathrm{w}$ planie dzieła, np. w scenariuszu scenicznym). Dlatego też odpowiedź odbiorcy może paść i nie musi. Dla zobrazowania takiego dialogu posłużmy się przykładem znanego performansu Lips of Thomas (Usta Tomasza) Mariny Abramović, wystawionego 24 października 1975 roku w galerii Krinzinger w Innsbrucku. Pokrótce prześledźmy opis spektaklu z publikacji badaczki sztuk performatywnych Eriki Fischer-Lichte.

Performerka zdjęła najpierw ubranie i naga podeszła do tylnej ściany galerii. Tam przypięła fotografię długowłosego mężczyzny, który wyglądem ją nieco przypominał. Następnie obrysowała fotografię konturem pięcioramiennej gwiazdy i zbliżyła się do stojącego obok stołu przykrytego białym obrusem, na którym stały butelka czerwonego wina, słoik miodu i kryształowy kieliszek. Obok leżały srebrna łyżeczka i pejcz. Abramović usiadła za stołem i powoli, łyżeczka po łyżeczce, zjadła cały kilogram miodu, potem powoli, kieliszek po kieliszku, wypiła całą butelkę wina. Gdy tego dokonała, prawą dłonią zgniotła kieliszek, dłoń zaczęła krwawić. Artystka wstała od stołu i znów podeszła do 
ściany z fotografią. Stojąc plecami do ściany, a przodem do widzów, żyletką wycięła sobie na brzuchu pięcioramienną gwiazdę, która naturalnie spłynęła krwią. Chwyciła pejcz, uklękła pod fotografią plecami do widzów i zaczęła się z całej siły biczować. Na plecach pojawiły się czerwone pręgi. Potem położyła się na wznak na blokach lodu, szeroko rozpościerając ramiona. $\mathrm{Na}$ suficie umieszczony został grzejnik, który skierował strumień ciepła na jej brzuch, co spowodowało ponowne krwawienie rany w kształcie gwiazdy. Artystka leżała bez ruchu, jakby zdecydowana cierpieć, aż ciepło grzejnika stopi lód. Gdy przez pół godziny nie dawała żadnego znaku, że chce przerwać męczarnie, kilku widzów nie wytrzymało napięcia, podeszło do bloków lodu, chwyciło performerkę i wyniosło ją, kończąc tym samym performans ${ }^{26}$. Poszczególne czynności artystki stanowiły komunikaty, jednakże żaden nie wzywał expressis verbis do reakcji. Performerka nie wołała np. o pomoc albo np. że chce wyjść z sali. Jej komunikaty tworzące dzieło sztuki stanowiły zamkniętą całość, która mogłaby zaistnieć bez konieczności reakcji. Niektórzy widzowie postanowili odpowiedzieć na ten komunikat swoimi czynami, ale nie zrobili tego wszyscy.

Z obu przytoczonych perspektyw dzieło sztuki wyłania się jako przestrzeń obcowania, która wyznacza granice dla odbiorcy: jeśli dzieło (wartości przez nie wyznaczone) przypadnie do gustu, wówczas odnajdzie się w przestrzeni obcowania i weźmie udział w dialogu. Dialogiczność dzieła może być więc zredukowana do tejże przestrzeni obcowania, np. w przypadku, gdy staje się ono powodem i przedmiotem dyskusji, tak jak chociażby w czasie spotkań wokół konkretnych wydarzeń artystycznych. Nie spełnia wtedy jednak funkcji quasi-podmiotowej, jak spełniało ją w pierwszym przypadku. Pozostaje ono na poziomie przedmiotowym, a tym,

26 Por. E. Fischer-Lichte, Estetyka performatywności, tłum. M. Borowski, M. Sugiera, Kraków 2008, s. 11-12. 
z którym odbiorca wchodzi w dialog, jest twórca. Stanowienie obszaru obcowania jednak nie wyczerpuje dialogicznych aspektów dzieła sztuki w dialogu między twórcą a odbiorcą. Istotniejsza, jak się wydaje, jest treść dzieła sztuki, składająca się na pewien komunikat twórcy skierowany do odbiorcy. Oczywiście nie każde dzieło sztuki, będące rzeczywiście dziełem, musi być tworzone z myślą o jakimkolwiek odbiorcy (w takim przypadku bardziej prawdopodobna będzie relacja między twórcą a dziełem - zob. pkt 2). Dzieło sztuki może stać się więc zdaniem wypowiedzianym w dialogu, z którym to zdaniem odbiorca zaczyna dialogować. Również w tym przypadku nie jest ono quasi-podmiotem dialogu, ale stanowi jego treść, jest jego sensem.

\section{Dialog między odbiorcą a dziełem}

Wszystko, co dotychczas zostało powiedziane o dziele sztuki i jego udziale w wydarzeniu spotkania, wymaga dopełnienia obrazu o trzeci wariant dialogu: sytuację, gdy odbiorca wchodzi w niego z dziełem sztuki rozumianym quasi-podmiotowo. Ów dia$\log \mathrm{w}$ wielu aspektach jest podobny do dialogu twórcy z dziełem. Wystarczy zatem poprzestać na tym, co nowego się w nim pojawia.

Dzieło sztuki jest tworem transcendentnym względem odbiorcy, dlatego to, co stanowi jego treść i co konstytuuje wartości, wchodzi od razu z odbiorcą w dialog. Dzieło mówi do odbiorcy całym sobą, komunikuje mu to, co ma do przekazania. Również tutaj pojawia się możliwość usprawiedliwienia lub potępienia albo wypracowania kompromisu. Wydaje się jednak, że relacja, jaka się wytworzyła, ma mniejsze napięcie niż w przypadku relacji twórcadzieło, lub może być nawet tego napięcia pozbawiona, gdy dialog z dziełem odbywa się na poziomie czysto intelektualnym, bez 
jakiegokolwiek zaangażowania emocjonalnego. W tym położeniu dzieło spełnia w pełni funkcję jednego z podmiotów dialogu, jest bowiem traktowane jako mówiące. Takie jego bycie możliwe jest wyłącznie wtedy, gdy koncentrujemy cały nasz dialogiczny wysiłek jedynie na nim.

Istnieje jednak moment, w którym dzieło sztuki w relacji z odbiorcą traci swój quasi-podmiotowy charakter na rzecz tworzenia przestrzeni obcowania lub stanowienia komunikatu dialogu. W przypadku gdy w dialog z dziełem sztuki zaczyna wchodzić świadomość istnienia konkretnego twórcy (wraz z równoczesnym pominięciem autonomii dzieła sztuki), mogą pojawiać się pytania o to, co autor chciał powiedzieć przez to dzieło, co sądzi o świecie, czym się kierował, pisząc je itd. W takim wypadku sam dialog z dziełem może okazać się niewystarczający, nie chcemy już bowiem pytać dzieła. Jesteśmy bardziej ciekawi, czy dobrze rozumiemy to, co wynieśliśmy ze spotkania $z$ nim. Ten moment powoduje, że dzieło zostaje sprowadzone $\mathrm{z}$ powrotem do funkcji przedmiotowych w dialogu.

Ważne jest to, że relacja do dzieła sztuki spełniającego funkcje podmiotowe $\mathrm{w}$ dialogu nie musi być tożsama $z$ relacją do jego twórcy. Dzieło sztuki może zostać usprawiedliwione przez odbiorcę, gdy ten sam odbiorca potępi (w sensie dialogicznym) twórcę i odwrotnie: potępione dzieło nie musi oznaczać potępienia odbiorcy. Podobnie: w dialogu z odbiorcą może zostać wypracowany kompromis, natomiast $z$ tym oto konkretnym jego dziełem już nie (sytuacja może być odwrócona).

\section{Perspektywy}

Dialogiczne aspekty dzieła sztuki sprawiają, że sama sztuka może nabierać nowej jakości i nowego znaczenia. Choć funkcje społeczne 
są sztuce znane od dawna, to jednak świadomość dialogicznych aspektów dzieła sztuki może mieć wpływ na sam proces jego tworzenia i odczytywania. Czy jednak wspomniane jakość i znaczenie okażą się lepsze? Wydaje się, że efekty mogą być dwojakie zarówno negatywne, jak i pozytywne.

Już Stróżewski zauważył, że tworzenie ze świadomością istnienia odbiorcy (nawet wirtualnego) nie zawsze może okazać się korzystne dla wartości dzieła ${ }^{27}$. Kiedy twórca stwarza coś pod publiczkę, istnieje obawa zafałszowania tego, co chce rzeczywiście powiedzieć. Także świadomość dialogicznych aspektów dzieła sztuki może doprowadzić do zredukowania go do nośnika komunikatów twórcy. Dzieło sztuki zostanie wówczas pozbawione należnych mu wartości estetycznych, które powinny odgrywać w nim główną rolę.

Pozytywną stroną dialogiczności dzieła sztuki może okazać się bardziej owocne prowadzenie dialogu. Może się to dziać w dialogu międzyludzkim, w którym spotykają się ze sobą dwa podmioty: twórca i odbiorca. Wydarzenie sensu, jakie konstytuuje się między nimi, może okazać się o wiele bardziej wartościowe dla obu podmiotów w sensie budowania ich osobowości, gdy przestrzenią obcowania i nośnikiem komunikatu będzie dzieło sztuki, oddziałujące na człowieka swoimi wszystkimi wartościami. Spotkanie zaś z dziełem sztuki sam na sam (zarówno dla obiorcy, jak i artysty) może mieć olbrzymie znaczenie w intymnym kształtowaniu osoby. Przeżycia dostarczane dzięki takim dialogom z pewnością podnoszą wartość człowieka i dialogu, w który on wchodzi niemal codziennie.

Największe wyzwanie dla dzieła sztuki stanowi więc zachowanie swoich wartości przy równoczesnym wypełnianiu funkcji dialogicznych, które dla człowieka są jednymi z najważniejszych, natomiast

27 Zob. W. Stróżewski, Dialektyka twórczości, dz. cyt., s. 217. 
dla dzieła sztuki nigdy nie będą sytuować się na pierwszym miejscu mimo ich doniosłej funkcji w społeczeństwie ludzkim.

\section{Wybrana bibliografia}

1. Borowski T., Prosze państwa do gazu, w: T. Borowski, Pożegnanie z Maria i inne opowiadania, Wrocław 2016, s. 81-102.

2. Fischer-Lichte E., Estetyka performatywności, tłum. M. Borowski, M. Sugiera, Kraków 2008.

3. Ingarden R., O poznawaniu dzieta literackiego, w: R. Ingarden, Studia z estetyki, t. 1, Warszawa 1966, s. 1-268.

4. Ingarden R., Utwór muzyczny i sprawa jego tożsamości, w: R. Ingarden, Studia z estetyki, t. 2, Warszawa 1966, s. 167-307.

5. Iwaszkiewicz J., Panny z Wilka, reż. A. Glińska, Narodowy Stary Teatr im. Heleny Modrzejewskiej w Krakowie [premiera: 1.03.2019].

6. Klqtwa, na motywach dramatu Stanisława Wyspiańskiego, reż. O. Frljić, Teatr Powszechny im. Zygmunta Hubnera w Warszawie [premiera: 18.02.2017].

7. Kłoczowski J. A., Filozofia dialogu, Poznań 2011.

8. Lévinas E., Etyka i nieskończony. Rozmowy z Philipp’em Nemo, tłum. B. Opolska-Kokoszka, Kraków 1991.

9. Louis É., Historia przemocy, tłum. J. Polachowska, Warszawa 2018.

10. Louis É., Jestem ulepiony ze wstydu, rozm. przepr. S. Eucyk, https://kultura.onet.pl/wywiady-i-artykuly/edouard-louis-jestem-ulepiony-ze-wstydu-wywiad/e61xx41 (21.05.2019).

11. Marciniakówna A., Od ttumaczki,w: H. Ibsen, Dom lalki (Nora); Upiory; Wróg ludu; Dzika kaczka; Rosmersholm, tłum. A. Marciniakówna, Warszawa 2014, s. 5-17. 
12. Strindberg A., Do Damaszku, reż.J. Klata, Narodowy Stary Teatr im. H. Modrzejewskiej w Krakowie [premiera: 5.10.2013].

13. Stróżewski W., Dzieło sztuki, w: W. Stróżewski, P. Taranczewski, Lubelskie wyktady o estetyce, Kraków 2016, s. 113-174.

14. Termer J., Uniwersalny stownik literatury, Warszawa 2006.

15. Tischner J., Filozofia dramatu, Kraków 2012. 
A/4 Uniwersytet Papieski

Tfon Jana Pawla II 